\title{
COMPARATIVE STUDY BETWEEN LIGHTWEIGHT MESH AND STANDARD PROLENE MESH IN LICHTENSTEIN HERNIA REPAIR
}

\author{
Mahesh Dhotre1, Shanmukhappa $S^{2}$
}

${ }_{1}^{1}$ Assistant Professor, Department of General Surgery, Sambhram Medical College, KGF, Karnataka, India.

${ }^{2}$ Resident Surgeon, Department of General Surgery, District Hospital, Haveri, Karnataka, India.

\begin{abstract}
BACKGROUND
ABSTRACT

Inguinal hernia repair is the most frequently performed operation in any general surgical unit. Reports on the outcome of inguinal hernia surgery show that recurrence rate 5 years after operation can vary from 0.1 to over 20\%. With Lichtenstein's hernioplasty, recurrence rate has come down to $<2 \%$. The trend changed in the early and mid 1990's in parallel with increasing number of case reports reporting mesh related complication after heavy mesh-based hernia repair such as seromas, discomfort, decreased abdominal wall mobility which are frequently observed post mesh hernioplasty.

The aim of the present study is to compare lightweight mesh with standard prolene mesh in Lichtenstein's hernia repair with respect to recurrence, serum, wound infection chronic pain and foreign body sensation at 1, 6 and 12 months follow-up and time taken to return to normal activity.
\end{abstract}

\section{MATERIALS AND METHODS}

A non-randomised controlled trial of 150 patients was undertaken. Patients were divided into two groups, of which 75 patients with primary lateral inguinal hernia were subjected to lightweight mesh Lichtenstein's hernioplasty and 75 to standard prolene mesh Lichtenstein's hernioplasty. All the hernia repairs were performed under spinal anaesthesia. In case of any associated conditions like hypertension and diabetes mellitus were present, treatment was first given for these associated conditions. The patients were followed in the surgical OPD at $1^{\text {st }}$ month, $6^{\text {th }}$ month and 1 year for time taken to return to normal activities, chronic groin pain, foreign body sensation, seroma formation and recurrence.

\section{RESULTS}

Chronic pain among patients in standard prolene mesh group at $1^{\text {st }}$ month, $6^{\text {th }}$ month and 1 -year follow-up was seen in $40 \%, 26.6 \%$ and $8 \%$ of the patients respectively. And chronic pain as seen in lightweight mesh group patients at $1^{\text {st }}$ month, $6^{\text {th }}$ month and 1 year follow-up was $20 \%, 9.33 \%$ and none at 1 year respectively. Foreign body sensation in the lightweight mesh group is significantly less compared to patients in standard prolene mesh group. There was no recurrence in both groups. Time to return to work was relatively shorter among patients in lightweight mesh group.

\section{CONCLUSION}

Use of lightweight mesh and standard prolene mesh in Lichtenstein's repair of inguinal hernia are both comparable and effective. Lightweight mesh with lesser amount of foreign body causes, less foreign body reaction and thus less chronic pain, lesser foreign body sensation and earlier return to normal activities, whereas recurrence is similar in both the groups. Thus, Lichtenstein's hernioplasty with lightweight mesh is an ideal choice whenever feasible.

\section{KEY WORDS}

Inguinal Hernia, Prolene Mesh, Lightweight Mesh, Tension Free Repair, Heavy Weight Mesh, Macro Porous Mesh, UltraPro Mesh, Vypro Mesh, Lightweight Mesh versus Standard Prolene Mesh, Lichtenstein's Hernia Repair.

HOW TO CITE THIS ARTICLE: Dhotre M, Shanmukhappa S. Comparative study between lightweight mesh and standard prolene mesh in Lichtenstein hernia repair. J. Evolution Med. Dent. Sci. 2018;7(30):3394-3400, DOI: 10.14260/jemds/2018/766

\section{BACKGROUND}

This non-randomised controlled trial of inguinal hernias are one of the most common surgical conditions faced by surgeons over the years. Bassini's repair was developed in the late $19^{\text {th }}$ century and revolutionary at the time for low recurrence rates compared to the previous standard of care procedures.

'Financial or Other Competing Interest': None.

Submission 03-07-2018, Peer Review 15-07-2018,

Acceptance 18-07-2018, Published 23-07-2018.

Corresponding Author:

Dr. Mahesh Dhotre,

Assistant Professor

Department of General Surgery,

Sambhram Medical College,

KGF, Karnataka, India.

E-mail: dhotre4u@gmail.com

DOI: $10.14260 /$ jemds $/ 2018 / 766$
It involved Bassini's triple layer (Internal oblique, transverse abdominis, fascia transversalis) to inguinal ligament with interrupted sutures with recurrence rates of 5 to $15 \% .^{1}$ Shouldice repair achieved recurrence rate below $2 \%$ at the hands of its originators, but failed to gain widespread acceptance due to its technical difficulties and inconsistent results outside shouldice clinic. ${ }^{2}$ The implantation of mesh and the resultant inflammatory reaction may also lead to the formation of a rigid scar plate with loss of abdominal wall pliability and changes in abdominal wall compliance, patients may complain of a sensation stiffness, physical discomfort and limitations in activities of daily living.

Lightweight meshes with reduced polypropylene content and larger pore size have demonstrated reduced inflammation and improved integration in surrounding tissues. They are also associated with decreased complaints of pain, paraesthesia and improved abdominal wall compliance while providing adequate strength. 


\section{Objectives}

To compare lightweight mesh with standard prolene mesh in Lichtenstein hernia repair with respect to recurrence, seroma, wound infection chronic pain and foreign body sensation and time taken to return to normal work at 1, 6 and 12 months follow-up.
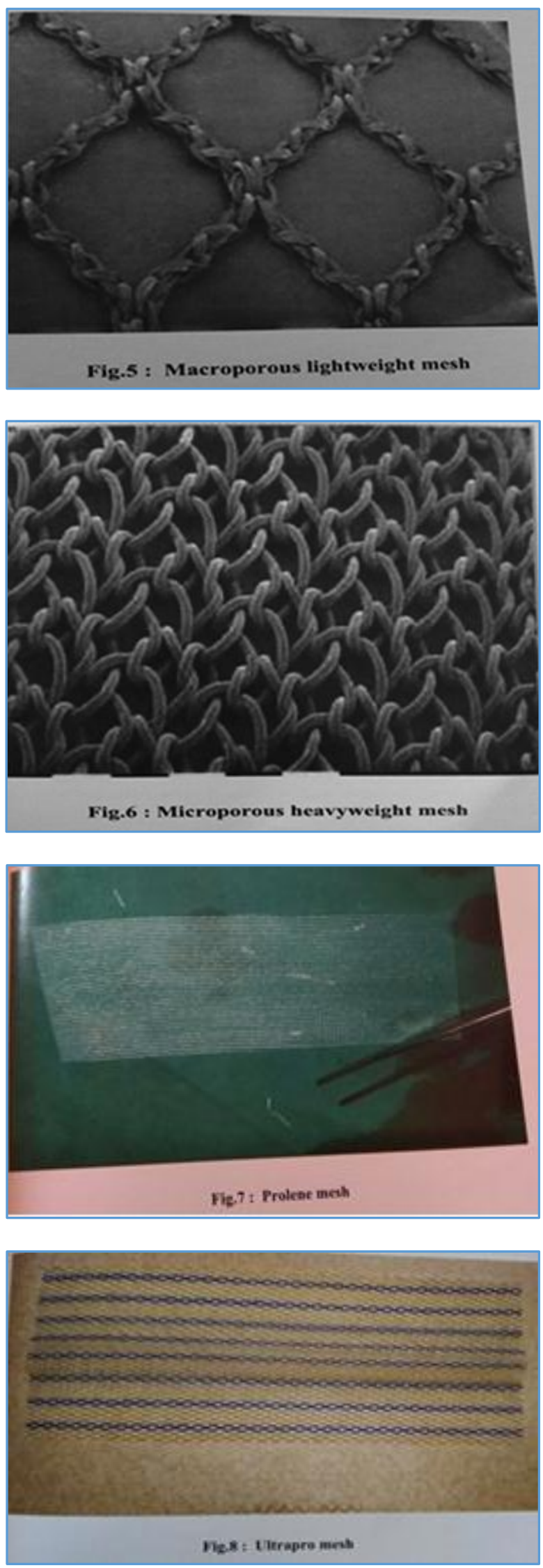

\section{MATERIALS AND METHODS}

This non-randomised controlled trial of total 150 patients were taken and divided into two groups, of which 75 patients with primary lateral inguinal hernia were subjected to lightweight mesh Lichtenstein's hernioplasty and 75 to standard prolene mesh Lichtenstein's hernioplasty in Chigateri General Hospital and Bapuji Hospital attached to JJM Medical College from June 2010 to June 2012. The patients admitted were subjected to Lightweight mesh (UltraPro) Lichtenstein's hernia. The patients admitted were subjected to standard prolene mesh Lichtenstein's hernia repair. The diagnosis of unilateral primary inguinal hernia was made on the basis of history of reducible groin swelling and essentially on clinical examination.

Only those investigations were done, which were relevant to obtain fitness for surgery. This included random blood sugar, blood urea, serum creatinine, ECG, Haemoglobin percentage and routine urine analysis for sugar, albumin and microscopy, chest x-ray and ultrasound abdomen. If any patient was found to have any medical contradiction for surgery, he was first treated for these medical problems and then re-evaluated for surgery.

All cases were done under spinal anaesthesia using $3 \mathrm{~mL}$ of bupivacaine $2 \%$ (Sensorcaine).

Patients admitted in the surgical wards were included in the study without bias on a serial basis. This is a comparative study comprising 75 patients of Inguinal Hernia, which was taken for convenience.

Since the calculated sample size was too high and thereby not feasible to include in this limited period of study, we had to limit the sample size for convenience.

\section{Inclusion Criteria}

- Men (20 yrs. or older) with unilateral primary inguinal hernias.

- $\quad$ Patients who gave consent for the procedure.

\section{Exclusion Criteria}

- Recurrent hernias.

- Presence of bowel obstructions, strangulation, peritonitis or perforation.

- Associated femoral hernia.

- Patients undergoing orchidectomy in the same procedure.

- $\quad$ Patients medically unfit for surgery.

Patients who refused investigations and any kind of surgical procedures were excluded.

\section{Statistical Analysis}

Statistical analysis was performed using the SPSS 16.0 (Statistical Package for the Social Science for windows; Version 16.0, SPSS Inc., Chicago, USA). Results were analysed using student's t-test for categorical variables and Chi-square test was used. Qualitative variables were analysed using proportions. Quantitative variables were analysed using mean and standard deviation. ' $\mathrm{P}$ ' value less than 0.05 was considered statistically significant. 

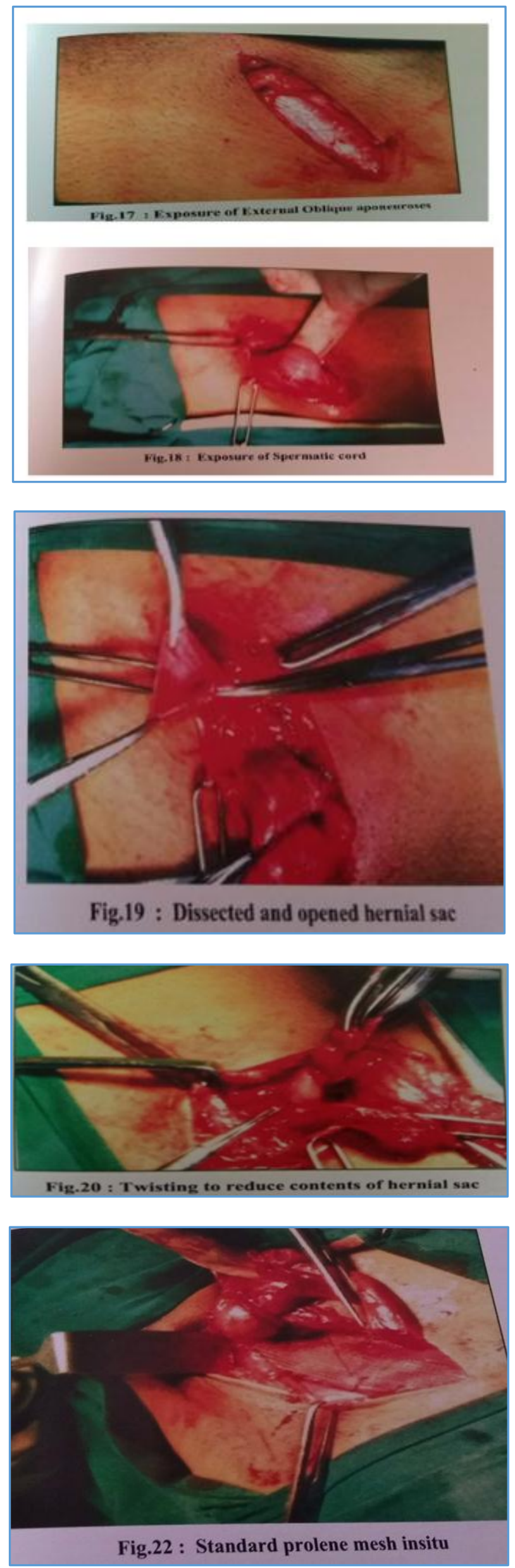
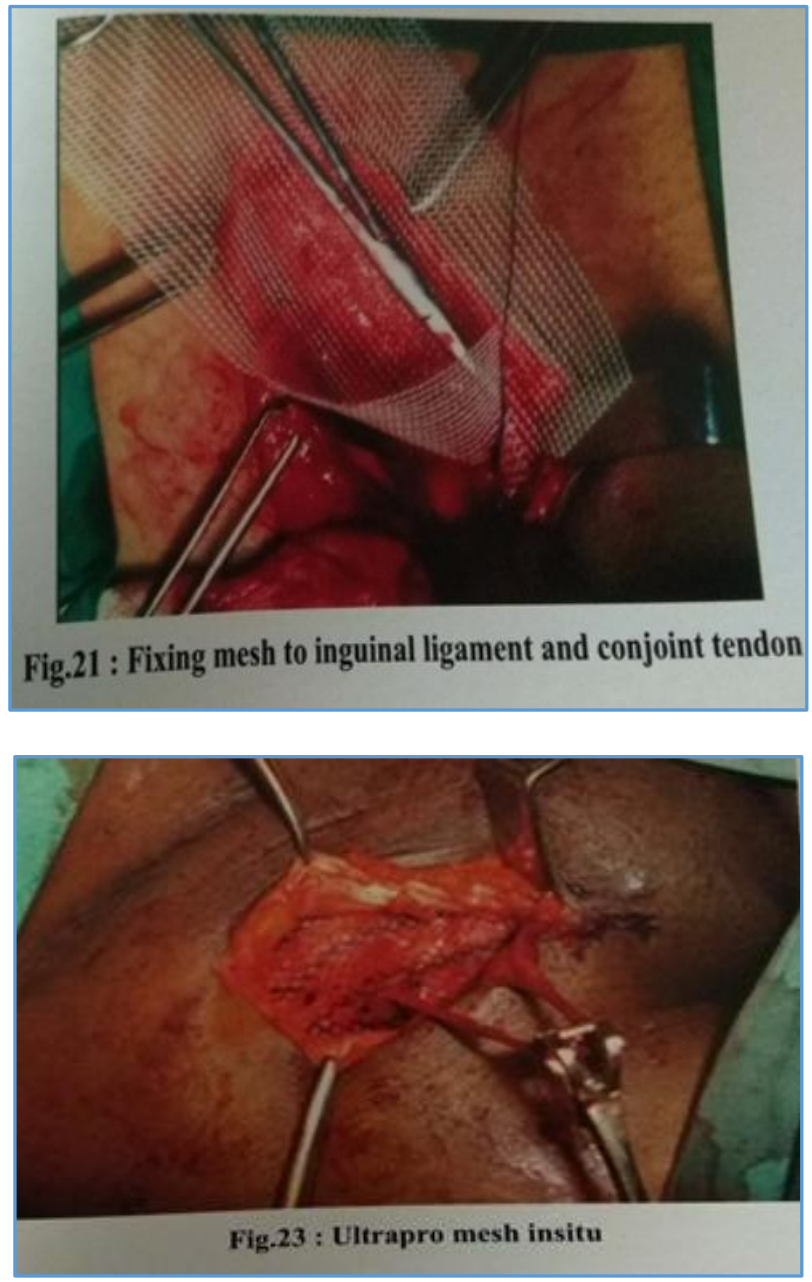

\section{RESULTS}

The present study was carried out in the Department of Surgery in Chigateri General Hospital and Bapuji Hospital attached to JJM Medical College at Davangere. 150 cases of unilateral primary inguinal hernia were included in the study after taking their consent. They were subjected to Lightweight mesh or standard prolene mesh Lichtenstein's hernia repair. Evaluation of all the patients included in the study was done regarding the history, physical findings, operative findings and post-operative complications. 75 underwent repair with lightweight mesh Lichtenstein's repair and 75 underwent repair with standard prolene mesh Lichtenstein's hernia repair. All the cases in both the groups were followed for a period of one year. The patients were followed up at $1^{\text {st }}$ month, $6^{\text {th }}$ month and one-year interval for any complication or recurrence. Any recurrence of hernia was considered an end point.

The following observations were made during the course of the study.

\begin{tabular}{|c|c|c|}
\hline $\begin{array}{c}\text { Age Group } \\
\text { (yrs.) }\end{array}$ & $\begin{array}{c}\text { Standard Prolene } \\
\text { Mesh n (\%) }\end{array}$ & $\begin{array}{c}\text { Lightweight Mesh } \\
\text { n (\%) }\end{array}$ \\
\hline $20-29$ & $9(12)$ & $26(34.66)$ \\
\hline $30-39$ & $8(10.67)$ & $8(10.67)$ \\
\hline $40-49$ & $10(13.33)$ & $6(8)$ \\
\hline $50-59$ & $18(24)$ & $9(12)$ \\
\hline $60-69$ & $20(26.67)$ & $18(24)$ \\
\hline $70+$ & $10(13.33)$ & $8(10.67)$ \\
\hline Total & $\mathbf{7 5}$ & $\mathbf{7 5}$ \\
\hline \multicolumn{2}{|c|}{ Table 1. Comparison of Age Wise distribution of Cases } \\
\hline
\end{tabular}




\begin{tabular}{|c|c|c|}
\hline Symptoms & $\begin{array}{c}\text { Standard } \\
\text { Prolene n (\%) }\end{array}$ & $\begin{array}{c}\text { Lightweight } \\
\text { Mesh n (\%) }\end{array}$ \\
\hline Swelling & $75(100)$ & $75(100)$ \\
\hline Pain & $40(53.33)$ & $36(48)$ \\
\hline \multicolumn{2}{|c|}{ Table 2. Comparison of associated Symptoms } \\
\hline
\end{tabular}

In both the groups, all patients presented with swelling in the groin $(100 \%)$ and pain was present in 36 cases $(48 \%)$ of patients in lightweight mesh group and 40 (53.33\%) of patients in standard prolene mesh group.

\section{Swelling}

\begin{tabular}{|c|c|c|}
\hline Duration & $\begin{array}{c}\text { Standard Prolene } \\
\text { Mesh n (\%) }\end{array}$ & $\begin{array}{c}\text { Lightweight Mesh } \\
\text { n (\%) }\end{array}$ \\
\hline$<1$ month & - & $3(4)$ \\
\hline $1-6$ months & $30(40)$ & $33(44)$ \\
\hline $6-12$ months & $3(4)$ & $3(4)$ \\
\hline $\begin{array}{c}12 \text { months }-2 \\
\text { years }\end{array}$ & $12(16)$ & $21(28)$ \\
\hline 2 years + & $30(40)$ & $15(20)$ \\
\hline Total & $\mathbf{7 5 ( 1 0 0 )}$ & $\mathbf{7 5 ( 1 0 0 )}$ \\
\hline \multicolumn{2}{|c|}{ Table 3. Comparison of Duration of Symptoms } \\
\hline
\end{tabular}

Range 1 month - 6 years, 15 days - 4 years

\section{Pain}

\begin{tabular}{|c|c|c|}
\hline Duration & $\begin{array}{c}\text { Standard Prolene } \\
\text { Mesh n (\%) }\end{array}$ & $\begin{array}{c}\text { Lightweight } \\
\text { Mesh n (\%) }\end{array}$ \\
\hline$<1$ month & - & 8 \\
\hline $1-6$ months & 19 & 25 \\
\hline $6-12$ months & 9 & - \\
\hline $\begin{array}{c}12 \text { months }-2 \\
\text { years }\end{array}$ & 6 & - \\
\hline 2 years+ & 6 & 3 \\
\hline Total & $\mathbf{4 0}$ & $\mathbf{3 6}$ \\
\hline
\end{tabular}

Range 1 month - 6 years, 15 days - 4 years.

A majority of patients in both groups presented with duration of swelling for 1 - 6 months. Similarly, majority of the patients in both groups presented with duration of pain of 1 - 6 months.

\begin{tabular}{|c|c|c|}
\hline & $\begin{array}{c}\text { Standard Prolene } \\
\text { Mesh n (\%) }\end{array}$ & $\begin{array}{c}\text { Lightweight } \\
\text { Mesh n (\%) }\end{array}$ \\
\hline Right & $49(65.33 \%)$ & $56(74.67)$ \\
\hline Left & $26(34.67 \%)$ & $19(25.33)$ \\
\hline Total & $75(100)$ & $75(100)$ \\
\hline \multicolumn{2}{|c|}{ Table 4(a). Comparison of Side Affected } \\
\hline
\end{tabular}

Numbers in parenthesis indicates numbers.

The majority of inguinal hernias in both the groups were right-sided.

\begin{tabular}{|c|c|c|}
\hline & $\begin{array}{c}\text { Standard Prolene } \\
\text { Mesh n (\%) }\end{array}$ & $\begin{array}{c}\text { Lightweight Mesh } \\
\text { n (\%) }\end{array}$ \\
\hline Direct & $23(30.67)$ & $19(25.33)$ \\
\hline Indirect & $52(69.33)$ & $56(74.67)$ \\
\hline Total & $\mathbf{7 5 ( 1 0 0 )}$ & $\mathbf{7 5 ( 1 0 0 )}$ \\
\hline \multicolumn{2}{|c|}{ Table 4(b). Comparison of Direct/Indirect Sac } \\
\hline
\end{tabular}

Numbers in parenthesis indicates numbers.

The majority of inguinal hernias in both the groups were right-sided.

\begin{tabular}{|c|c|c|}
\hline $\begin{array}{l}\text { Associated } \\
\text { Factors }\end{array}$ & $\begin{array}{c}\text { Standard Prolene } \\
\text { Mesh n (\%) }\end{array}$ & $\begin{array}{l}\text { Lightweight } \\
\text { Mesh n (\%) }\end{array}$ \\
\hline Smoker & $18(24)$ & $18(24)$ \\
\hline $\begin{array}{c}\text { Benign Enlargement } \\
\text { of Prostate (BEP) }\end{array}$ & $3(4)$ & $3(4)$ \\
\hline Bronchitis + BEP & $3(4)$ & $3(4)$ \\
\hline Diabetes Mellitus & $6(8)$ & $9(12)$ \\
\hline Hypertension (HTN) & $6(8)$ & $6(8)$ \\
\hline Bronchial Asthma & - & $3(4)$ \\
\hline HTN + BEP & - & $3(4)$ \\
\hline $\begin{array}{c}\text { Smoker, Urethral } \\
\text { Stricture }\end{array}$ & - & $3(4)$ \\
\hline NIL & $39(52)$ & $27(36)$ \\
\hline Total & $75(100)$ & $75(100)$ \\
\hline \multicolumn{3}{|c|}{ Table 5. Comparison of Associated Factors } \\
\hline
\end{tabular}

Numbers in parenthesis indicates numbers.

The most common factor associated with inguinal hernia in both the groups was smoking accounting for $24 \%$ of them.

\begin{tabular}{|c|c|c|c|c|c|c|c|c|c|}
\hline & \multicolumn{4}{|c|}{ Standard Prolene Mesh } & \multicolumn{3}{c|}{ Lightweight Mesh } & $\begin{array}{c}\text { Fisher's } \\
\text { Exact Test } \\
\text { (P-value) }\end{array}$ \\
\cline { 2 - 8 } & $\begin{array}{c}\text { No Pain } \\
\text { (N) }\end{array}$ & $\begin{array}{c}\text { Mild Pain } \\
\text { (m) }\end{array}$ & $\begin{array}{c}\text { Moderate } \\
\text { Pain (M) }\end{array}$ & $\begin{array}{c}\text { Severe } \\
\text { Pain (S) }\end{array}$ & $\begin{array}{c}\text { No Pain } \\
\text { (N) }\end{array}$ & $\begin{array}{c}\text { Mild Pain } \\
\text { (m) }\end{array}$ & $\begin{array}{c}\text { Moderate } \\
\text { Pain (M) }\end{array}$ & $\begin{array}{c}\text { Severe } \\
\text { Pain (S) }\end{array}$ & $\begin{array}{c}\text { (main } \\
\text { significant }\end{array}$ \\
\hline $\begin{array}{c}\text { Post- } \\
\text { op } \\
\text { Day 7 }\end{array}$ & $40(53.33)$ & $30(40)$ & $5(6.67)$ & - & $45(60)$ & $25(33.33)$ & $5(6.67)$ & - & -7041 Not \\
\hline \multicolumn{7}{|c|}{ Table 6. Comparison of Pain on Post-Operative Day 7 } \\
\hline
\end{tabular}

Numbers in parenthesis indicates numbers.

There is no significant difference between lightweight mesh group and standard prolene mesh group with respect to pain at post-op 7.

\begin{tabular}{|c|c|c|}
\hline & Standard Prolene Mesh n (\%) & Lightweight Mesh n (\%) \\
\hline Haematoma & $3(4)$ & $4(5.33)$ \\
\hline Seroma & $3(4)$ & $2(2.67)$ \\
\hline Infection & $3(4)$ & $6(8)$ \\
\hline Normal & $66(88)$ & $63(84)$ \\
\hline Total & $\mathbf{7 5 ( 1 0 0 )}$ & $\mathbf{7 5 ( 1 0 0 )}$ \\
\hline Table 7. Comparison of Post-Operative Complications on Day-7 - Haematoma/Seroma/Wound Infection \\
\hline
\end{tabular}

Numbers in parenthesis indicates numbers. 


\begin{tabular}{|c|c|c|c|c|c|c|c|c|c|}
\hline & \multicolumn{4}{|c|}{ Standard Prolene Mesh } & \multicolumn{4}{|c|}{ Lightweight Mesh } & \multirow{2}{*}{$\begin{array}{c}\text { Fisher's } \\
\text { Exact Test } \\
\text { (p-value }\end{array}$} \\
\hline & $\begin{array}{c}\text { No Pain } \\
\text { (N) }\end{array}$ & $\begin{array}{l}\text { Mild Pain } \\
\text { (m) }\end{array}$ & $\begin{array}{c}\text { Moderate } \\
\text { pain (M) }\end{array}$ & $\begin{array}{c}\text { Severe } \\
\text { pain }(S)\end{array}$ & $\begin{array}{c}\text { No Pain } \\
\text { (N) }\end{array}$ & $\begin{array}{c}\text { Mild } \\
\text { pain (m) }\end{array}$ & $\begin{array}{c}\text { Moderate } \\
\text { pain (M) }\end{array}$ & $\begin{array}{c}\text { Severe } \\
\text { pain (S) }\end{array}$ & \\
\hline $\begin{array}{c}1^{\text {st }} \\
\text { month }\end{array}$ & $45(60)$ & $30(40)$ & - & - & $60(80)$ & $15(20)$ & - & - & $0.0122(\mathrm{~S})$ \\
\hline $\begin{array}{c}6^{\text {th }} \\
\text { month }\end{array}$ & $55(73.33)$ & $20(26.67)$ & - & - & $68(90.66)$ & $7(9.33)$ & - & - & $0.0024(\mathrm{~S})$ \\
\hline 1 year & $69(92)$ & $6(8)$ & - & - & $75(100)$ & - & - & - & $0.0282(\mathrm{~S})$ \\
\hline
\end{tabular}

Numbers in parenthesis indicates numbers.

Chronic pain is significantly less in the lightweight mesh group patients compared with standard prolene mesh patients at $1^{\text {st }}$ month, $6^{\text {th }}$ month and 1-year post surgery.

\begin{tabular}{|c|c|c|c|c|}
\hline Groups & $\begin{array}{c}\text { Range } \\
\text { (Days) }\end{array}$ & Mean \pm SD & $\mathbf{t}^{*}$ & P \\
\hline $\begin{array}{c}\text { Standard } \\
\text { prolene } \\
\text { mesh }\end{array}$ & $\begin{array}{c}11-35 \\
\text { days }\end{array}$ & $15.85 \pm 4.54$ & & \\
\cline { 1 - 3 } $\begin{array}{c}\text { Light- } \\
\text { weight } \\
\text { mesh }\end{array}$ & $\begin{array}{c}11-30 \\
\text { days }\end{array}$ & $13.97 \pm 3.61$ & 2.8083 & $\begin{array}{c}<0.0057, \\
\mathrm{HS}\end{array}$ \\
\hline \multicolumn{7}{|c|}{ Table 9. Comparison of Time Taken to Resume Normal } \\
Activities or Convalescence Period \\
\hline
\end{tabular}

*Unpaired t-test.

Time taken to resume normal activities was significantly less in case of light weight hernioplasty as compared to standard prolene mesh hernioplasty.

\begin{tabular}{|c|c|c|c|c|}
\hline \multirow{2}{*}{} & \multicolumn{2}{|c|}{$\begin{array}{c}\text { Standard Prolene } \\
\text { Mesh }\end{array}$} & \multicolumn{2}{c|}{$\begin{array}{c}\text { Lightweight } \\
\text { Mesh }\end{array}$} \\
\cline { 2 - 5 } & Yes & No & Yes & No \\
\hline 1 month & - & $75(100)$ & - & $75(100)$ \\
\hline 6 months & - & $75(100)$ & - & $75(100)$ \\
\hline 1 year & - & $75(100)$ & - & $75(100)$ \\
\hline \multicolumn{3}{|c|}{ Table 10. Comparison of Recurrence } \\
\hline
\end{tabular}

Numbers in parenthesis indicates numbers.

None of the patients in both the mesh groups had any recurrences during the follow-up period.

\begin{tabular}{|c|c|c|c|c|}
\hline & Standard Prolene Mesh n (\%) & Lightweight Mesh n (\%) & Chi-Square Value & P-value \\
\hline Yes & $22(29.33)$ & $8(10.67)$ & 8.17 & $<0.01$ \\
\hline No & $53(70.67)$ & $67(89.33)$ & & \\
\hline \multicolumn{2}{|r|}{ Table 11. Comparison of Foreign Body Sensation } \\
\hline
\end{tabular}

Numbers in parenthesis indicates numbers.

$\mathrm{P}$ value $<0.01$ indicates foreign body sensation in the lightweight mesh group is significantly less compared to the foreign body sensation in standard prolene mesh group.

\begin{tabular}{|c|c|c|c|c|c|c|}
\hline & \multicolumn{2}{|c|}{ Standard Prolene Mesh } & \multicolumn{2}{|c|}{ Lightweight Mesh } & \multirow{2}{*}{$\begin{array}{c}\text { Chi-Square } \\
\text { Value }\end{array}$} & \multirow{2}{*}{ P-value } \\
\hline & Yes (\%) & No (\%) & Yes (\%) & No (\%) & & \\
\hline 1 month & $3(4)$ & $72(96)$ & $2(2.67)$ & $73(97.33)$ & 0.2069 & $0.6492(\mathrm{NS})$ \\
\hline 6 months & $0(0)$ & $75(100)$ & $0(0)$ & $75(100)$ & & \\
\hline 1 year & $0(0)$ & $75(100)$ & $0(0)$ & $75(100)$ & & \\
\hline \multicolumn{7}{|c|}{ Table 12. Comparison of Seroma Formation } \\
\hline
\end{tabular}

Numbers in parenthesis indicates numbers.

There is no significant difference in seroma formation between standard prolene mesh group and lightweight mesh group at $1^{\text {st }}$ month, $6^{\text {th }}$ month and 1-year follow-up.

\section{DISCUSSION}

All inguinal hernias share the common feature of emerging through the myopectineal orifice of Fruchaud, the opening in the lower abdominal wall bounded above by the myoaponeurotic arch of the lower edges of the internal oblique and the transverse abdominis muscle and below by the pectineal line of the superior pubic ramus.

Inguinal hernia surgeries are one of the most frequently performed operations in general surgery and as such even minor alterations in the outcome have appreciable impact. As surgeons we want techniques with short learning curves, but we still want to attain results comparable to the specialist hernia surgeons.
Our patients on the other hand want their period of convalescence and rehabilitation to be uncomplicated in both short- and long-term outcome, so as to return to their normal daily activities. They need less pain and better quality of life post-operatively with minimal surgical morbidity in the long term.

Currently, Two Major Techniques of Hernia Repair Exist-

- Pure tissue repairs.

- Tension free or mesh repairs. 
The present comparative study is a small study and follow-up is limited for a period of one year. Therefore, there is a limitation to the study.

\section{Recurrence}

In this study during the period of one-year follow-up there was not even a single case of recurrence in both mesh repair groups.

\begin{tabular}{|c|c|c|c|c|c|}
\hline \multirow{2}{*}{ Study } & \multicolumn{2}{|c|}{ Standard Prolene Mesh } & \multirow{2}{*}{ Study } & \multicolumn{2}{|c|}{ Lightweight Mesh } \\
\hline & Follow-Up & Recurrence (\%) & & Follow-Up & Recurrence (\%) \\
\hline S Bringman et al ${ }^{3}$ & 3rd year & $9(3.7)$ & S Bringman et al & 3rd year & $9(3.6)$ \\
\hline PJO Dwyer et al ${ }^{4}$ & 1 year & $1(0.7)$ & PJO Dwyer et al & 1 year & $8(5.6)$ \\
\hline M Smietanski et al $^{5}$ & 1 year & $1(0.6)$ & M Smietanski et al & 1 year & $4(1.9)$ \\
\hline S Post et al 6 & 6 months & $2(4.2)$ & S Post et al & 6 months & $2(3.4)$ \\
\hline Present Study & 1 year & 0 & Present Study & 1 year & 0 \\
\hline & To & Recurrence $\mathrm{F}$ & pared with Othe & & \\
\hline
\end{tabular}

The recurrence rate in the present study is comparable with other studies.

\section{Chronic Pain}

In the present study, follow-up of standard prolene mesh group patients revealed that $45(60 \%)$ patients had no pain and 30 $(40 \%)$ patients had mild pain at $1^{\text {st }}$ month, $55(73.33 \%)$ patients had no pain and $20(26.67 \%)$ patients had mild pain at $6^{\text {th }}$ month and $69(92 \%)$ patients had no pain and $6(8 \%)$ patients had mild pain at 1 year follow-up period.

Follow-up of lightweight mesh group patients revealed that $60(80 \%)$ patients had no pain and $15(20 \%)$ patients had mild pain at $1^{\text {st }}$ month, $68(90.67 \%)$ patients had no pain and $7(9.33 \%)$ patients had mild pain at $6^{\text {th }}$ month and $75(100 \%)$ patients had no pain at 1 year follow-up period.

\begin{tabular}{|c|c|c|c|c|c|}
\hline \multirow{2}{*}{ Study } & \multicolumn{2}{|c|}{ Standard Prolene Mesh } & \multirow{2}{*}{ Study } & \multicolumn{2}{|c|}{ Lightweight Mesh } \\
\hline & Follow-Up & Recurrence (\%) & & Follow-Up & Recurrence (\%) \\
\hline S Bringman et al 3 & 3 year & $3.3 \%$ & S Bringman et al & 3 year & $0.8 \%$ \\
\hline PJO Dwyer et al ${ }^{4}$ & $\begin{array}{l}1 \text { month } \\
3 \text { month }\end{array}$ & $\begin{array}{l}81.8 \% \\
56.6 \% \\
\end{array}$ & PJO Dwyer et al & $\begin{array}{l}1 \text { month } \\
3 \text { month }\end{array}$ & $\begin{array}{l}82.1 \% \\
56.8 \% \\
\end{array}$ \\
\hline M Smietanski et al ${ }^{5}$ & $\begin{array}{c}7 \text { days } \\
3 \text { months } \\
6 \text { months } \\
12 \text { months }\end{array}$ & $\begin{array}{c}55.2 \% \\
17.1 \% \\
9.9 \% \\
6.2 \% \\
\end{array}$ & M Smietanski et al & $\begin{array}{c}7 \text { days } \\
3 \text { months } \\
6 \text { months } \\
12 \text { months }\end{array}$ & $\begin{array}{c}36.2 \% \\
9.8 \% \\
10.7 \% \\
3.8 \% \\
\end{array}$ \\
\hline Present Study & $\begin{array}{c}7 \text { days } \\
1 \text { month } \\
6 \text { months } \\
12 \text { months }\end{array}$ & $\begin{array}{c}46.67 \% \\
40 \% \\
26.67 \% \\
8 \%\end{array}$ & Present Study & $\begin{array}{c}7 \text { days } \\
1 \text { month } \\
6 \text { months } \\
12 \text { months }\end{array}$ & $\begin{array}{c}40 \% \\
20 \% \\
9.33 \% \\
0 \%\end{array}$ \\
\hline & & Chronic & d with Other & & \\
\hline
\end{tabular}

\section{Time to Return to Normal Activity}

Return to normal activities and work can be dependent on nutritional status of the patient. Malnourished patients are likely to have longer periods of convalescence.

In the present study, standard prolene mesh group patient's range is 11 - 35 days with mean value of 15.85 days and lightweight mesh group range being 11 - 30 days with mean value of 13.97 days.

It should be noted that desk workers will usually return to work earlier than manual workers. Time taken to work may also be dependent on financial incentives a patient gets at place of work.

\begin{tabular}{|c|c|c|c|}
\hline Study & Standard Prolene Mesh(T) & Study & Lightweight Mesh (T) \\
\hline PJO Dwyer et al & 26 days & PJO Dwyer et al & 21 days \\
\hline Present Study & 15.85 days & Present Study & 13.97 days \\
\hline \multicolumn{2}{|r|}{ Table 15. Time Taken to reduce Normal Activities (Convalescence Period) compared with Other Studies } \\
\hline
\end{tabular}

\section{Foreign Body Sensation}

It is understood that lightweight mesh with less amount of foreign body causes less reaction and less body sensation. In this study, 22 people in the standard prolene mesh group had foreign body sensation compared to 8 people in lightweight mesh group.

\begin{tabular}{|c|c|c|c|}
\hline Study & Standard Prolene Mesh (\%) & Study & Lightweight Mesh (\%) \\
\hline S Bringman et al $^{3}$ & $55(22.6 \%)$ & S Bringman et al & $37(14.7 \%)$ \\
\hline S Post et al $^{6}$ & $21(43.8 \%)$ & S Post et al & $10(17.2 \%)$ \\
\hline Present Study & $22(29.33 \%)$ & Present study & $8(10.67 \%)$ \\
\hline \multicolumn{2}{|c|}{ Table 16. Foreign Body Sensation compared with Other Studies } \\
\hline
\end{tabular}

Foreign body sensation is in the present study comparable to other studies. 


\section{CONCLUSION}

Use of lightweight mesh and standard prolene mesh in Lichtenstein's repair of inguinal hernia are both comparable and effective lightweight mesh with lesser amount of foreign body causes less foreign body reaction and thus less chronic pain, lesser foreign body sensation and earlier return to normal activities, whereas recurrence is similar in both the groups. Seroma formation, immediate pain, wound infection and haematoma is not affected but the type of mesh used. Lichtenstein's inguinal hernioplasty with lightweight mesh is an ideal choice whenever it is feasible.

\section{REFERENCES}

[1] Woods B, Neumayer L. Open repair of inguinal hernia: an evidence-based review. Surgical Clinics of North America 2008;88(1):139-55.

[2] Gray SH, Hawn MT, Itani KM. Surgical progress in inguinal and ventral incisional hernia repair. Surgical Clinics of North America 2008;88(1):17-26.
[3] Bringman S, Wollert S, Osterberg JZ, et al. Three-year results of a randomized clinical trial of lightweight or standard polypropylene mesh in Lichtenstein repair of primary inguinal hernia. Br J Surg 2006;93(9):1056-9.

[4] O'Dwyer PJ, Kingsnorth AN, Molloy RG, et al. Randomised clinical trial assessing impact of a lightweight or heavyweight mesh on chronic pain after inguinal hernia repair. British Journal of Surgery 2005; 92(2):166-70.

[5] Smietanski M, Polish Hernia Study Group. Randomised clinical trial comparing a Polypropylene with poliglecaprone and polypropylene composite mesh for inguinal hernioplasty. British Journal of Surgery 2008;95(12):1462-8.

[6] Post S, Weiss B, Willer M, et al. Randomised clinical trial of lightweight composite mesh for Lichtenstein inguinal hernia repair. British Journal of Surgery 2004;91(1):44-8. 